\title{
Thalassaemia and glucose-6-phosphate dehydrogenase deficiency in sickle-cell disorder patients in Taiz, Yemen
}

H.A. Al-Nood ${ }^{1}$

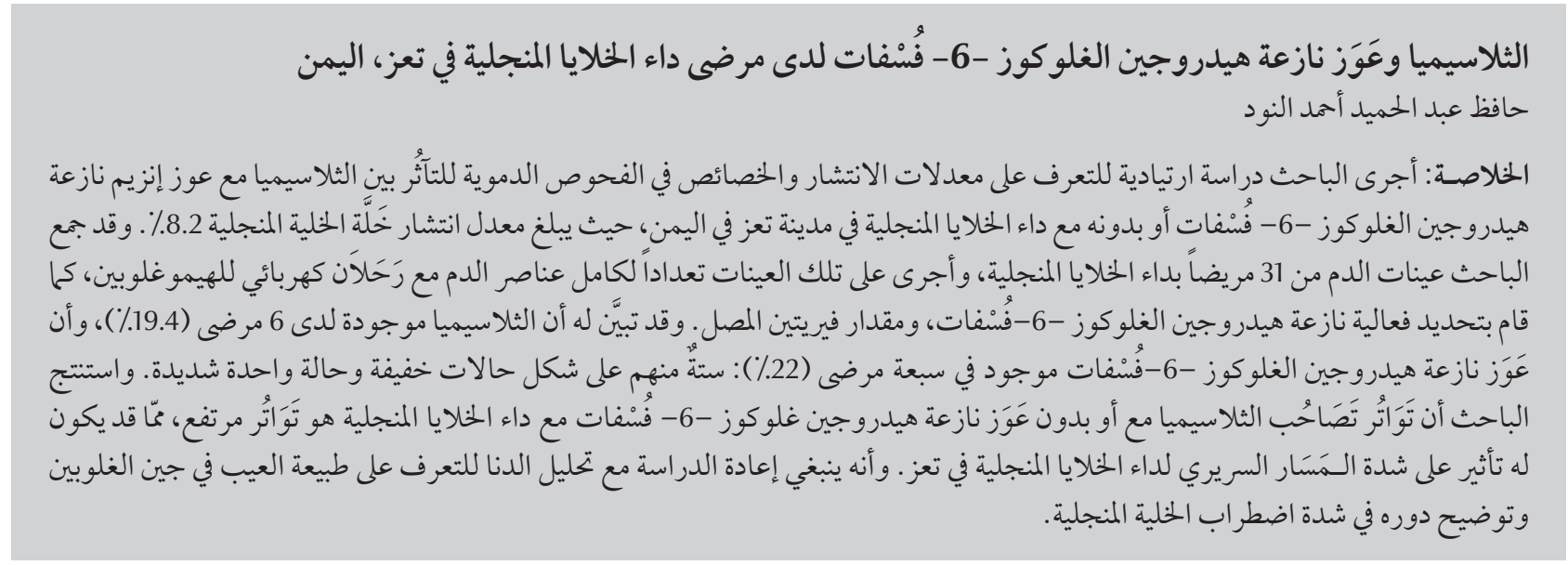

ABSTRACT A pilot study was conducted to determine the prevalence and haematological characteristics of the interaction between thalassaemia or/and glucose-6-phosphate dehydrogenase (G6PD) deficiency in patients with sickle-cell disorder (SCD) in Taiz city, Yemen, where the prevalence of sickle-cell trait (HbAS) is $8.2 \%$. Blood samples were collected from 31 SCD patients. Complete blood count and haemoglobin electrophoresis, G6PD activity and serum ferritin were determined. Thalassaemia was found in 6 patients (19.4\%) and G6PD deficiency (6 mild and 1 severe) was detected in 7 patients (22.6\%). The frequency of thalassaemia and/or G6PD deficiency with SCD was high and this may have an effect on the severity of the clinical course of SCD in Taiz. The study should be repeated with DNA analysis to define the nature of the globin gene defect and to clarify its role in the severity of SCD.

\section{Thalassémie et déficit en glucose-6-phosphate déshydrogénase chez des patients atteints de drépanocytose à} Taïz (Yémen)

RÉSUMÉ Une étude pilote a été conduite pour déterminer la prévalence de la thalassémie et/ou du déficit en glucose-6-phosphate déshydrogénase (G6PD) chez des patients atteints de drépanocytose et pour analyser les caractéristiques hématologiques de leur interaction avec la drépanocytose dans la ville de Taïz au Yémen, où la prévalence du trait drépanocytaire (HbAS) est de 8,2\%. Des échantillons de sang ont été prélevés chez 31 patients atteints de drépanocytose. Des analyses ont été réalisées pour déterminer les résultats d'une numération formule sanguine, d'une électrophorèse de l'hémoglobine, de l'activité de la glucose-6-phosphate déshydrogénase et de la ferritine sérique. Le diagnostic de thalassémie a été posé chez six patients $(19,4 \%)$ et celui de déficit en glucose-6-phosphate déshydrogénase chez sept patients (22,6\%), parmi lesquels six patients étaient atteints d'une forme modérée et un patient d'une forme sévère. La fréquence de l'association de la thalassémie ou/ et du déficit en glucose 6 phosphate déshydrogénase à la drépanocytose était élevée et pourrait influer sur la sévérité de l'évolution clinique de la drépanocytose à Taïz. Il serait souhaitable de reconduire la présente étude en analysant l'ADN pour définir la nature de l'anomalie du gène de la globine et pour clarifier son rôle dans le degré de sévérité de la drépanocytose. 


\section{Introduction}

Sickle-cell disorder (SCD), thalassaemia, and glucose-6-phosphate dehydrogenase (G6PD) deficiency are inherited disorders causing haemolytic anaemia in humans. SCD and thalassaemia are the most common genetic disorders worldwide [1].

The clinical manifestations of SCD are due to the tendency for the haemoglobin $(\mathrm{Hb}) \mathrm{S}$ variant to polymerize and deform red blood cells into the sickle shape under deoxygenated conditions. The homozygous state of $\mathrm{HbS}$ is the most common form of SCD [1], but its interaction with thalassaemia and certain variant haemoglobins also leads to sickling and may affect its clinical picture. Interaction of SCD with thalassaemia and G6PD deficiency has been reported in many studies $[2,3]$, since all of these disorders share the characteristic that their carriers have partial protection against malaria infection. The high prevalence of these genetic defects in certain human populations may be due to the selective pressure of malaria [4].

Yemen is located on the south-west of the Arabian peninsula and has a population of 21 million [5]. It is estimated that the annual number of cases of malaria infection in Yemen are around 3 million [6]. The overall prevalence of sickle-cell trait (HbAS) in Yemen is $2.2 \%$, with a higher frequency in the mid-western region where Taiz city is located than in the central and eastern areas [7]. Theprevalenceofthalassaemia trait in Yemen is $13.3 \%$ ( $\beta$-thalassaemia trait $4.4 \%$, $\alpha$-thalassaemia trait $8.9 \%$ ) [8]. There are no previous reports on the occurrence of G6PD deficiency or thalassaemia in Yemeni SCD patients, except one showing that the coexistence of $\boldsymbol{\alpha}$-thalassaemia in 26 Yemeni children with SCD living in Riyadh was $57.7 \%$ [9].

The present pilot study was conducted to determine the prevalence and haematological characteristics of the interaction between thalassaemia or/and G6PD deficiency in patients with SCD in Taiz, where the prevalence of HbAS is $8.2 \%$ [7]. Such studies are essential to evaluate how these conditions impact on the severity of the clinical features of SCD and to clarify their role in childhood mortality and morbidity.

\section{Methods}

Between November and December 2007, blood samples were collected from 31 patients with SCD attending the Yemen Society for Thalassaemia and Genetic Blood Disorders in Taiz city ( 18 males, 13 females, aged between 6 months to 18 years) who came from different territories of Taiz governorate (Table 1$)$.

Two venous blood samples (1 collected into EDTA, 1 clotted) were collected from each patient. The first one was used for determination of: complete blood count (CBC), using the Sysmex KX-21N 2 haematology analyser (Sysmex Corporation); separation of haemoglobin variants, using high-performance liquid chromatography (HPLC) (Bio-Rad); G6PD activity, using a quantitative assay kit (Randox Laboratories); and sickling test, using the sodium metabisulfate method. The second sample was used for estimation of the serum ferritin level, using the AxSym fluorescence microparticle enzyme immunoassay method (Abbott). Blood films were stained with Leishman stain.

Presence of SCD was defined by a positive sickling test and $\mathrm{HbS}$ concentration $>50 \%$ of the total $\mathrm{Hb}$ by high-pressure liquid chromatography. Thalassaemia was indicated by microcytic hypochromic red cells: mean corpuscular volume $(\mathrm{MCV})<80 \mathrm{fL}$ and/ or mean corpuscular haemoglobin $(\mathrm{MCH})<27 \mathrm{pg}$, after adjustment of the $\mathrm{MCV} / \mathrm{MCH}$ for each age group with normal or high serum ferritin. Normal range for serum ferritin was 20-260 ng/mL; high serum ferritin was $>260 \mu \mathrm{g} / \mathrm{L}$; low serum ferritin was $<20 \mu \mathrm{g} / \mathrm{L}$.

Patients were defined as:

- $\quad \mathrm{SCD}+$ thalassaemia: coexistence of SCD with microcytic hypochromic red cells with normal or high serum ferritin.

- $\mathrm{SCD}+\mathrm{G} 6 \mathrm{PD}$ deficiency: coexistence of SCD with G6PD deficiency.

- $\mathrm{SCD}+$ thalassaemia + G6PD deficiency: coexistence of SCD with microcytic hypochromic red cells, normal serum ferritin and G6PD deficiency.

High level of fetal $\mathrm{Hb}(\mathrm{HbF})$ was $>20 \%$. A high nucleated red blood cell (RBC) count was $\geq 1$ and high white blood cell (WBC) count was $\geq 10$ $\times 10^{9} / \mathrm{L}$

\section{Results}

All the samples showed a positive sickling test. No HbA was detected in any of them. The distribution of the cases by sex, rate of SCD, rate of SCD + thalassaemia and rate of SCD + G6PD deficiency by territory of Taiz city is presented in Table 1 . A total of 19 cases (61.3\%) showed SCD without thalassaemia or G6PD deficiency, 6 (19.4\%) were considered as SCD + thalassaemia and $7(22.6 \%)$ were SCD + G6PD deficiency ( 6 cases of mild $>20-<65 \%$ and 1 case of severe G6PD deficiency $<20 \%)$. Only 1 SCD case (3.2\%) was considered as SCD + thalassaemia + G6PD deficiency.

There were 30 SCD samples (96.8\%) that showed high serum ferritin: 24 had levels between 260 and $1000 \mu \mathrm{g} / \mathrm{L}$ and 6 had levels $>1000$ $\mu \mathrm{g} / \mathrm{L}$. Only 1 sample showed serum ferritin $(53 \mathrm{ng} / \mathrm{mL})$ within the normal range. No SCD samples with low serum ferritin were reported in this study. 


\begin{tabular}{|c|c|c|c|c|c|c|}
\hline \multirow[t]{2}{*}{ District } & \multicolumn{6}{|c|}{ No. of samples } \\
\hline & Total & Male & Female & SCD & $\begin{array}{c}\text { SCD + } \\
\text { thalassaemia }\end{array}$ & $\begin{array}{r}\text { SCD + G6PD } \\
\text { deficiency }^{\text {b }}\end{array}$ \\
\hline Al Maafer & 1 & 1 & 0 & 1 & 0 & 0 \\
\hline Al Modaffer & 4 & 3 & 1 & 4 & 0 & 0 \\
\hline Al Qaherah & 4 & 3 & 1 & 2 & $2^{\mathrm{a}}$ & $1^{\mathrm{a}}$ \\
\hline Al Taiziah & 2 & 2 & 0 & 1 & 0 & 1 \\
\hline Al Wazzehia & 1 & 1 & 0 & 1 & 0 & 0 \\
\hline Demnat Hader & 1 & 1 & 0 & 1 & 0 & 0 \\
\hline Jabal Habashi & 4 & 0 & 4 & 3 & 1 & 0 \\
\hline Kadas & 1 & 0 & 1 & 1 & 0 & 0 \\
\hline Makbannah & 2 & 0 & 2 & 0 & 1 & 1 \\
\hline Saber & 1 & 1 & 0 & 1 & 0 & 0 \\
\hline Sharrab & 4 & 2 & 2 & 1 & 1 & 2 \\
\hline Alselw & 1 & 0 & 1 & 0 & 1 & 0 \\
\hline Bny Hammd & 1 & 1 & 0 & 0 & 0 & 1 \\
\hline Mawiyh & 2 & 2 & 0 & 1 & 0 & 1 \\
\hline Al Raboay & 2 & 1 & 1 & 2 & 0 & 0 \\
\hline \multicolumn{7}{|l|}{ All districts } \\
\hline No. & 31 & 18 & 13 & 19 & 6 & 7 \\
\hline$\%$ & 100.0 & 58.1 & 41.9 & 61.3 & 19.4 & 22.6 \\
\hline
\end{tabular}

${ }^{a} 7$ case had SCD + thalassaemia + G6PD deficiency; ${ }^{b}$ case had severe G6PD deficiency.

Of the SCD samples, 30 showed nucleated RBCs and 12 (38.7\%) showed a high nucleated RBC count in the blood film (between 10\%-58\%). Of these, 6 cases had nucleated RBCs $>20 \%$ and 2 cases $>50 \%$.

The mean values of the haematological parameters in cases of SCD and SCD + thalassaemia or SCD + G6P deficiency are shown in Table 2. The cases of SCD + G6PD deficiency had slightly higher total $\mathrm{Hb}$ than the cases of SCD or SCD + thalassaemia. The SCD + thalassaemia cases had the lowest total $\mathrm{Hb}$, the highest $\mathrm{WBC}$ count and the highest percentage of nucleated RBCs. However, the WBC count was high in SCD, SCD + thalassaemia and SCD + G6PD deficiency.

The 4SCD cases with $\mathrm{HbF}>20 \%$ (2 with SCD, 1 with SCD + thalassaemia, 1 with SCD + G6PD deficiency) showed higher total $\mathrm{Hb}$ and lower $\mathrm{WBC}$ counts than the 27 SCD cases with $\mathrm{Hb} \mathrm{F}<20 \%$ (Table 3).

\section{Discussion}

This study showed that in Taiz region the prevalence of thalassaemia among SCD patients was $19.4 \%$, whereas the prevalence of mainly mild G6PD deficiency with SCD was $22.6 \%$. Only 1 of the 31 samples showed an association of SCD with both thalassaemia and G6PD deficiency. Absence of $\mathrm{HbA}$ in all the samples of this study indicated that these cases could be homozygous sickle cell, sickle cell/ $\beta$-thalassaemia, homozygous sickle cell $/ \beta$-thalassaemia or homozygous sickle cell/athalassaemia.

The diagnosis of thalassaemia was based on low MCV $<80 \mathrm{fL}$ and/or $\mathrm{MCH}<27 \mathrm{pg}$, after adjustment of the $\mathrm{MCV} / \mathrm{MCH}$ for each age group with normal or high serum ferritin. Using the $\mathrm{HbA2}$ level for distinguishing between $\alpha$ - and $\beta$-thalassaemia traits in this study was not appropriate because its level may overlap, since $\mathrm{HbA} 2$ may be raised in the presence of $\mathrm{HbS}$, $\mathrm{SCD} / \alpha$-thalassaemia and the heterozygous compound of $S / \beta$-thalassaemia $[10,11]$.

Of the SCD samples, 12 showed a high percentage of nucleated RBCs: 6 had $>20 \%$ nucleated RBCs and 2 had $>50 \%$. This high number of cases with nucleated RBCs reflects the level of hyper-erythropoiesis, suggesting a high presence of young RBCs which may mask the diagnosis of G6PD deficiency type $\mathrm{A}(-)$, since these immature RBCs are rich with G6PD [12]. Therefore, the prevalence of G6PD deficiency interaction with SCD may have been underestimated in this study or the detection of severe G6PD deficiency may have been masked in patients with SCD.

Of all the samples 30 showed high serum ferritin $>260 \mathrm{ng} / \mathrm{mL}, 6$ of which had serum ferritin $>1000 \mathrm{ng} /$ $\mathrm{mL}$, suggesting that these patients were either not using the chelating agent 


\begin{tabular}{|c|c|c|c|}
\hline \multirow[t]{2}{*}{ Haematological parameters } & $\begin{array}{c}\text { SCD } \\
(n=19) \\
\text { (age } 1.5-18 \text { yrs) }\end{array}$ & $\begin{array}{c}\text { SCD + thalassaemia } \\
(n=6)^{\mathrm{a}} \\
(\text { age } 0.5-9 \text { yrs })\end{array}$ & $\begin{array}{c}\text { SCD + G6PD deficiency } \\
(n=7)^{\mathrm{a}} \\
(\text { age 6-7 yrs })\end{array}$ \\
\hline & Mean (SD) & Mean (SD) & Mean (SD) \\
\hline $\mathrm{Hb}(\mathrm{g} / \mathrm{dL})$ & $6.9(1.4)$ & $6.6(2.4)$ & $7.9(3.2)$ \\
\hline $\mathrm{PCV}(\mathrm{L} / \mathrm{L})$ & $21.4(4.0)$ & $21.2(7.5)$ & $23.9(2.5)$ \\
\hline $\operatorname{RBC}\left(\times 10^{12} / \mathrm{L}\right)$ & $2.31(0.25)$ & $2.91(1.31)$ & $2.77(0.34)$ \\
\hline WBC $\left(\times 10^{9} / \mathrm{L}\right)$ & $13.9(5.2)$ & $14.8(4.4)$ & $13.1(4.7)$ \\
\hline $\operatorname{MCV}(f L)$ & $93.3(7.8)$ & $74.0(6.9)$ & $87.4(7.6)$ \\
\hline $\mathrm{MCH}(p g)$ & $29.9(3.30)$ & $23.0(2.4)$ & $28.9(3.1)$ \\
\hline $\mathrm{MCHC}(\mathrm{g} / \mathrm{dL})$ & $32.0(1.8)$ & $31.0(1.2)$ & $32.4(1.7)$ \\
\hline Nucleated RBCs (\%) & $10.3(15.1)$ & $13.7(19.4)$ & $7.3(10.6)$ \\
\hline $\mathrm{HbS}(\%)$ & $86.0(7.2)$ & $87.0(9.3)$ & $85.6(8.1)$ \\
\hline $\mathrm{HbF}(\%)$ & $9.7(7.6)$ & $8.5(9.9)$ & $9.5(9.1)$ \\
\hline $\mathrm{HbA} 2(\%)$ & $4.3(1.3)$ & $4.5(2.0)$ & $4.9(1.4)$ \\
\hline Serum ferritin $(\mathrm{ng} / \mathrm{mL})$ & $707(592)$ & $1174(919)$ & $611(615)$ \\
\hline G6PD deficiency ( $\left.\mathrm{mU} / 10^{9} \mathrm{RBC}\right)$ & $127(16)$ & $90.0(26)$ & $45.0(15)$ \\
\hline
\end{tabular}

${ }^{a} 7$ case had SCD + thalassaemia + G6PD deficiency.

$H b=$ haemoglobin; $P C V=$ packed cell volume; $R B C=$ red blood cells; $W B C=$ white blood cells; $M C H=$ mean corpuscular haemoglobin; $M C H C=$ mean corpuscular haemoglobin concentration; $M C V=$ mean corpuscular volume; HbS= sickle haemoglobin; HbF= fetal haemoglobin; HbA2 = haemoglobin alpha 2. $n=$ number of samples.

(deferoxamine mesylate) or used it improperly. Chronic infection may also play a role in this as the mean $\mathrm{WBC}$ count was high for these SCD patients, although an increased WBC count in SCD may be partially due to a shift of granulocytes from the marginated pool of cells to the circulating pool. In this study normal and high serum ferritin levels were considered as indicators for the absence of iron deficiency.

The slightly higher RBC counts in cases of SCD + thalassaemia than cases of SCD + SCD + G6PD deficiency is in accordance with the increased RBC counts in thalassaemia trait which may support the diagnosis of thalassaemia [13]. The slightly higher WBC counts and lower level of total $\mathrm{Hb}$ in SCD + thalassaemia cases suggests that coexistence of thalassaemia + SCD worsens the severity of SCD.

This study showed a correlation between a high level of $\mathrm{HbF}$ (> 20\%) and higher total $\mathrm{Hb}$ and lower WBC counts than those with low $\mathrm{HbF}(<20 \%)$, which may indicate that a high level of $\mathrm{HbF}$ has a beneficial effect on the clinical picture of SCD, as previously reported in other studies [14].

The slightly higher total $\mathrm{Hb}$ in cases of SCD + G6PD deficiency than those with SCD and SCD + thalassaemia may support the theory of simultaneous inheritance of G6PD deficiency and sickle-cell anaemia. This is because in G6PD deficiency, SCD increases the number

Table 3 Relationship of total haemoglobin ( $\mathrm{Hb}$ ) level and white blood cell (WBC) count with fetal haemoglobin $(\mathrm{HbF})$ level

\begin{tabular}{lcccc} 
Variable & $\begin{array}{c}\text { No. of } \\
\text { samples }\end{array}$ & $\begin{array}{c}\mathrm{HbF} \\
(\%)\end{array}$ & $\begin{array}{c}\text { Total Hb } \\
(\mathrm{g} / \mathbf{d L})\end{array}$ & $\begin{array}{c}\text { WBC } \\
\left(\times \mathbf{1 0}^{9} / \mathrm{L}\right) \\
\text { Mean }\end{array}$ \\
$\begin{array}{l}\text { Mean } \\
\mathrm{HbF}<20 \%\end{array}$ & 27 & 7.1 & 6.9 & 14.9 \\
$\mathrm{HbF} \geq 20 \%$ & 4 & 27.4 & 7.9 & 8.5 \\
\hline
\end{tabular}

of reticulocytes that are rich in the G6PD enzyme, and in SCD, G6PD deficiency increases the numbers of young RBCs and decreases the old RBCs which decrease the irreversibly sickled erythrocytes [12]

This study represents the first attempt to determine the prevalence of interaction of thalassaemia and/ or G6PD deficiency in patients with SCD in Taiz. The prevalence of thalassaemia in SCD was $19.4 \%$, less than that found previously in Yemeni children living in Riyadh by El-Hazmi et al. [9]. Further investigation is warranted using DNA techniques in order to accurately diagnose those who are found to have microcytic red cells and to study the nature of the mutations involved for predicting the likely severity of the clinical course of SCD in association with thalassaemia and/or G6PD deficiency. A larger study is required to identify the effect of the $\alpha$ - or $\beta$-thalassaemia, G6PD deficiency and the other genetic $\mathrm{Hb}$ defect disorders on the severity of the clinical picture of SCD in Yemen. 


\section{Acknowledgements}

The auther is grateful to the research group students: Eman A. Fitahy, Teesir A. Babker, Eman Y. Al-Gzhy, Nebras K.
Hussin, Ghadh H. Al-Flahy, Naeemh Thanks are aldo due to the staff of the M. Gidy, Mohamed A. Al-Hakemi, Abdulah A. Shamsan, Maher A. Al-Grshy and Tofeek S. Al-Durh for their efforts in the sample collection and analysis.
Department of Haematology at $\mathrm{Al}$ Saeed hospital in Taiz city for allowing us to use their laboratory instruments for the sample analysis.

\section{References}

1. Modell B, ed. Guidelines for the control of haemoglobin disorders. Geneva, World Health Organization, 1994 (WHO/HDP/ $\mathrm{HB} / 94.1)$.

2. El-Hazmi MA, Warsy AS. Appraisal of sickle-cell and thalassaemia genes in Saudi Arabia. Eastern Mediterranean Health Journal, 1999, 5(6):1147-1153.

3. El-Hazmi MA, Warsy AS. Interaction between glucose-6-phosphate dehydrogenase deficiency and sickle cell gene in Saudi Arabia. Tropical and Geographical Medicine, 1987, 39:32-35.

4. Kolata G. The search for a malaria vaccine. Science, 1984, 226:679-682.

5. Statistical year book 2004. Sana'a, Yemen, Central Statistical Organization. Ministry of Planning and Development, 2004.

6. Lambeth S. Health care in the Yemen Arab Republic. International Journal of Nursing Studies, 1988, 25:171-177.

7. Al-Nood $\mathrm{H}$ et al. Prevalence of the sickle cell gene in Yemen: a pilot study. Hemoglobin, 2004, 28:305-315.

8. Al-Nood HA. Thalassemia trait in outpatient clinics of Sana'a city, Yemen. Hemoglobin, 2009, 33:242-246.
9. El-Hazmi MAF, Warsy AS. Alpha thalassaemia in Yemeni children with sickle cell disease. Journal of Tropical Pediatrics, 1999, 45:370-374.

10. Serjeant GR et al. The clinical features of sickle-cell-thalassaemia in Jamaica. British Journal of Haematology, 1973, 24:19-30.

11. Higgs DR et al. The interaction of alpha-thalassemia and homozygous sickle-cell disease. New England Journal of Medicine, 1982, 306:1441-1446.

12. Piomelli $\mathrm{S}$ et al. Clinical and biochemical interactions of glucose-6-phosphate dehydrogenase deficiency and sickle-cell anemia. New England Journal of Medicine, 1972, 287:213-217.

13. Mouélé $\mathrm{R}$ et al. alpha-thalassemia in Bantu population from Congo-Brazzaville: its interaction with sickle cell anemia. $\mathrm{Hu}$ man Heredity, 2000, 50:118-125.

14. Gelpi AP. Benign sickle cell disease in Saudi Arabia: survival estimate and population dynamics. Clinical Genetics, 1979, 15:307-310. 